\title{
ISOLATION AND CHARACTERIZATION OF
} CELLULOLYTIC BACTERIA ENTEROBACTER XIANGFANGENSIS FROM THE GUT OF
ARMOURED CATFISH PTERYGOPLICHTHYS MULTIRADIATUS

\author{
R. Jayasuyra \\ PG \& Research Department of Biotechnology \\ Srimad Andavan Arts and Science College, Trichy
}

\author{
T. Sathish Kumar \\ PG \& Research Department of Biotechnology \\ Srimad Andavan Arts and Science College, Trichy \\ S. Arif Nisha \\ PG \& Research Department of Biotechnology \\ Srimad Andavan Arts and Science College, Trichy
}

\begin{abstract}
Armoured catfish is a tropical bottom dwelling fish, which feeds mainly on algae and aquatic weeds as their major part of diet. In the present study, the cellulolytic bacterial strain Enterobacter xiangfangensis was isolated from gut of armoured catfish Pterygoplichthys multiradiatus and it was identified based on morphological test and 16s rRNA gene sequencing. The isolated strain was assessed for cellulolytic activity. The results of the present study suggest that the new strain was rod shaped and catalase positive. The strain was found to effectively hydrolyze Carboxy methyl cellulose, which suggests that the isolate exhibited cellulolytic activity. Phylogenetic tree was constructed by neighbourhood joining method. Upon successful extraction of the cellulase, the enzyme can be used in industrial production of cellulase enzyme in a costeffective manner.
\end{abstract}

Keywords- Pterygoplichthys multiradiatus, Armoured catfish, Enterobacter Xiangfangensis, Cellulase, Pleco fish

\section{INTRODUCTION}

The armoured catfish Pterygoplichthys multiradiatus is a tropical fish belongs to the Loricariidae family with 92 genera and over 680 species. Bony plated body and sucker mouth are the special morphological abilities of this family. $P$. multiradiatus is a fresh water tropical fish native to the streams and shallow fresh water bodies in tropical and subtropical region of South America. They are popularly known as suckermouth catfish and pleco fish. In South America these fishes are known as cascudos or acaris. These fishes shows a behaviour based on grazing, being found near to the bottom of the creek on rocks, logs and submerged plants, scraping the periphyton matrix (Castro et al. 2011). It mainly feeds on algae and aquatic weeds but will also feed on larvae and other bottom living invertebrates as food.

$P$. multiradiatus are introduced as aquarium fish in world wide. The ever increasing global trade of ornamental aquarium fishes is one of the most important and yet poorly documented pathways for aquatic bio invasion (Rixon et al. 2005). One third of the world's worst aquatic invasive species are ornamental fishes (Padilla \& Williams 2004). South American sucker mouth armoured cat fish (Loricariidae) are popular throughout the world as aquarium pets because of their characteristic attractive appearance and use in aquarium as cleaner to remove the algae (Pijukumar et al. 2015). Pterygoplichthys is one of the fast dispersing species in the invaded countries, introduced primarily through uncontrolled pet trade and their invasion results in serious ecological and economic consequences (Nico et al. 2012). The sucker mouth armoured catfish Pterygoplichthys sp. have successfully invaded inland water bodies of various countries across the world including Philippines (Hubilla et al. 2007), Japan (Nakoba 2002), Taiwan (Wu et al. 2011), Vietnam (Zworykin \& Budaev 2013), Srilanka (Sumanasinghe \& Amarasinghe 2013), Indonesia, Malaysia, Singapore (Page \& Robins 2006), Israel (Golani \& Snovsky 2013), Turkey (Ozdilek 2007), Bangladesh (Hossain et al. 2008), Mexico (Armando et al. 2007). The suckermouth armoured catfishes reported from India include $P$. multiradiatus from Kerala and Tamilnadu (Knight. 2010). By local people it is regarded as a harmful invasive species being inedible to consume for people and predators. It is mainly causing damage to the fishing gears, competing and harming the native fish species in the local 


\section{International Journal of Engineering Applied Sciences and Technology, 2020 \\ Vol. 5, Issue 1, ISSN No. 2455-2143, Pages 696-701 \\ Published Online May 2020 in IJEAST (http://www.ijeast.com)}

water bodies and disrupting the aquatic ecosystem by its burrowing activities and collapses the aquatic food chain by consuming the aquatic insect larvae.

Cellulose consists of a $\beta$-1,4-glycosidic linkages and is estimated as the most abundant biomass 1015 metric tons (Wilson et al. 1999) in the world and therefore have the greatest potential to resolve both the energetic and environmental demands of bioenergy. In order to break the cellulose compound for the energy or biofuel it requires cellulase enzyme.

The term "cellulases" refers to a group of enzymes that catalyze the hydrolysis of conversion of cellulose into sugars. Cellulolytic microorganisms play an important role in the biosphere by recyling cellulose, the most abundant carbohydrate produced by plants (Beguin 1990). Cellulose and hemicellulose are the most abundant biomasses on earth, and therefore have the greatest potential to resolve both the energetic and environmental demands of bioenergy. Complete cellulose hydrolysis to glucose demands the action of exoglucanases (also called cellobiohydrolyses), endoglucanases and $\beta$-glucosidases. Thus the animals that feed on the substances that are cellulosic in nature require the aid of symbiotic microorganisms in their GI tract to digest cellulose and generate energy, which will be available to the host (Bergman 1990). P. multiradiatus mainly consumes algae and aquatic plants as their primary diet. The algal cell wall is made up of cellulose and hence there is an expectation of symbiotic relationship between armoured catfish and a cellulolytic microorganism to produce cellulase enzyme. Nowadays, Cellulases are required in large quantities because of their application in many industries, such as textiles, detergent, food, animal feed, bio-fuel, paper and pulp, pharmaceutical, and waste management (Ramesh et al. 2008). Therefore, isolation of industrially important cellulase producing microorganism from various unexplored sources will develop the production of cellulase and improves the economic status of our country. In line to this context, the present study aims at isolation of cellulase degrading organism from the gut of pleco fish.

\section{MATERIALS \& METHODS}

\section{A. Sample collection}

Two samples were collected from two different environment. The first sample was collected from the local aquarium shop located in Thiruvanaikovil, Trichirapalli, South India.

The second sample was collected from the Geethapuram $\left(10^{\circ} 48^{\prime} 18^{\prime \prime} \mathrm{N} 78^{0} 41^{\prime} 08^{\prime} \mathrm{E}\right)$, located in the banks of Cauvery river, Trichy, Tamil Nadu, India. The fish samples were collected manually by netting in shallow water.

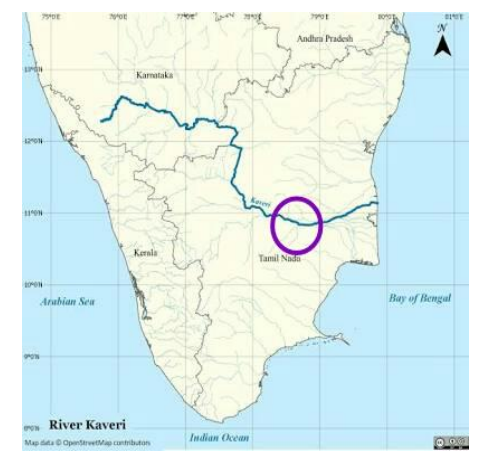

Fig. 1. Cauvery river

Courtesy:https://en.m.wikipedia.org/wiki/File:River_Cauvery_EN.png

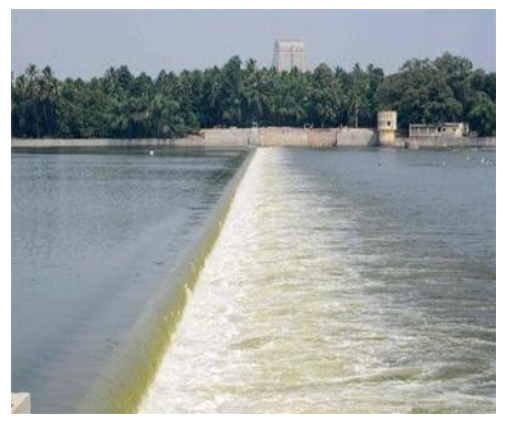

Fig. 2. Geethapuram shutter dam

Courtesy: https://www.google.co.in/amp/s/m.timesofindia.com/city/ trichy/Remains-of-Vinayaka-idols-add-to-pollution-of-Cauvery- river-inTrichy/amp_articleshow/54320223.cms?source=images

The fishes were 4 inches in length and 20 grams in weight. The fishes were immediately taken to laboratory for dissection in aseptic conditions.

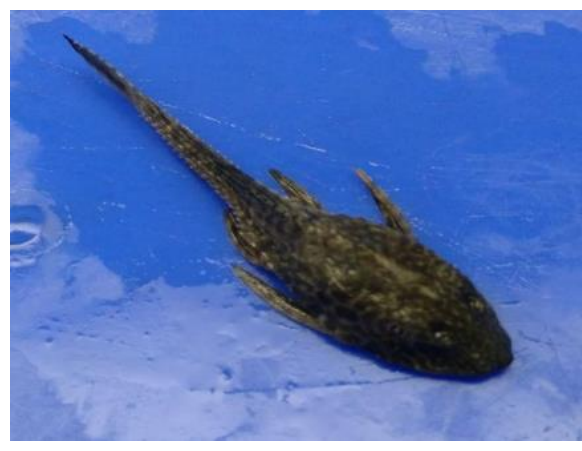

Fig. 3. Pterigoplichthys multiradiatus

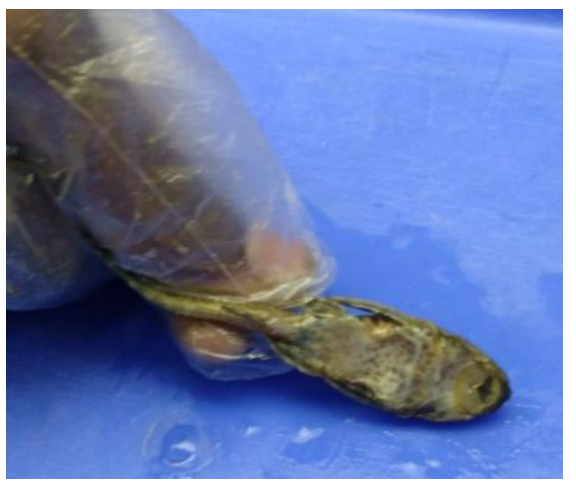




\section{International Journal of Engineering Applied Sciences and Technology, 2020 \\ Vol. 5, Issue 1, ISSN No. 2455-2143, Pages 696-701 \\ Published Online May 2020 in IJEAST (http://www.ijeast.com)}

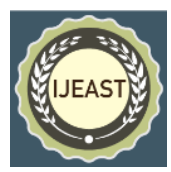

\section{Fig. 4. Pterigoplichthys multiradiatus mid ventral region}

\section{B. Isolation of cellulolytic microorganism:}

The food content from the digestive tract of the different fish samples was transferred to sterilized tubes and portions of $200 \mathrm{mg}$ were mixed with $1.8 \mathrm{ml}$ of saline (Castro et al. 2011). The sample was serially diluted and were plated in Carboxy methyl cellulose agar (CMC agar : $\mathrm{NH}_{4} \mathrm{H}_{2} \mathrm{PO}_{4}-1 \mathrm{~g}$; KCL $0.2 \mathrm{~g} ; \mathrm{MgSO}_{4} .7 \mathrm{H}_{2} \mathrm{O}-1 \mathrm{~g} ; \quad$ Yeast extract $-1 \mathrm{~g} ; \mathrm{CMC}-26 \mathrm{~g}$; Agar $-3 \mathrm{~g}$ diluted in $1000 \mathrm{ml}$ distilled water). After $48 \mathrm{~h}$ of incubation at $32^{\circ} \mathrm{C}$, different colonies were isolated based on their morphology. The isolates were cultured and maintained at $4^{\circ} \mathrm{C}$.

\section{Detection of cellulolytic activity:}

After the incubation period, the bacterial cells were flooded with $5 \mathrm{ml}$ of Congo red $(0.1 \%)$ and washed with $\mathrm{NaCl}(1 \%)$. The cellulolytic strains were identified by the formation of a clear halo around the bacterial growth (Bairagi et al. 2002).

\section{Evaluation of Cellulase activity:}

The pre-inoculum of the selected strain was inoculated in 100 $\mathrm{ml}$ minimal broth containing $0.2,0.4,0.6,0.8,1.0 \mathrm{~g}$ of filter papers. The flasks were incubated at Room Temperature for 5 days. The cellulase activity was assayed by measuring the amount of reducing sugars. This was performed by Dinitrosalicylic acid (DNS) method.

\section{E. Characterization of the gut isolate:}

Cellular morphology was observed on crystal violet stained smears on compound microscope. Cellular motility was observed in fresh wet mounts of overnight bacterial cultures in Carboxymethyl cellulose medium. Catalase activity was determined by bubble production in a $3 \%$ hydrogen peroxide solution.

\section{F. 16SrRNA gene sequencing and phylogenetic analysis:}

\section{DNA Extraction:}

Lysis/homogenization: Cells were grown in monolayer and was lysed by suspending 1-3 colonies aseptically and mixed with $450 \mu \mathrm{l}$ of "B Cube" lysis buffer in a $2 \mathrm{ml}$ micro centrifuge tube and lyse the cells by repeated pipetting.

$4 \mu \mathrm{l}$ of RNAse A and $250 \mu \mathrm{l}$ of "B Cube" neutralization buffer were added.

The content was vortexed and incubated the tubes for 30 minutes at $65^{\circ} \mathrm{C}$ in water bath. To minimize shearing of the DNA molecules, mix DNA solutions by inversion.
The tubes were centrifuged for 20 minutes at $14,000 \mathrm{rpm}$ at $10^{\circ} \mathrm{C}$

Following centrifugation, the resulting viscous supernatant was transferred into a fresh $2 \mathrm{ml}$ micro centrifuge tube without disturbing the pellet.

$600 \mu \mathrm{l}$ of "B Cube" binding buffer was added to the content and mixed thoroughly by pipetting and incubated the content at room temperature for 5 minutes.

$600 \mu \mathrm{l}$ of the contents were transferred to a spin column placed in $2 \mathrm{ml}$ collection tube.

Centrifuged for 2 minutes at 14,000 rpm and discarded the flow-through.

Then the remaining $600 \mu \mathrm{l}$ of the lysate was transferred.

Centrifuged for 2 minutes at 14,000 rpm and discarded flow-through.

$500 \mu \mathrm{L}$ "B Cube" washing buffer I was added to the spin column. Centrifuged at $14,000 \mathrm{rpm}$ for $2 \mathrm{mins}$ and discarded flow-through

The spin column was ressembled and added $500 \mu \mathrm{l}$ "B Cube" washing buffer II and Centrifuged at 14,000 rpm for 2 mins and discarded flow-through

The spin column was transferred to a sterile $1.5-\mathrm{ml}$ micro centrifuge tube

$100 \mu \mathrm{l}$ of "B Cube" Elution buffer was added at the middle of spin column. Care should be taken to avoid touch with the filter.

The tubes were incubated for 5 mins at room temperature and Centrifuged at $6000 \mathrm{rpm}$ for $1 \mathrm{~min}$.

The above mentioned steps were repeated for 14 and 15 for complete elution. The buffer in the micro centrifuge tube contains the DNA.

DNA concentrations were measured by running aliquots on $1 \%$ agarose gel.

The DNA samples were stored at $-20^{\circ} \mathrm{C}$ until further use. PCR

Polymerase Chain Reaction (PCR) is a process that uses primers to amplify specific cloned or genomic DNA sequences with the help of a very unique enzyme. PCR uses the enzyme DNA polymerase that directs the synthesis of DNA from deoxynucleotide substrates on a single-stranded DNA template. DNA polymerase adds nucleotides to the $3^{\prime}$ end of a custom-designed oligonucleotide when it is annealed to a longer template DNA. Thus, if a synthetic oligonucleotide is annealed to a single-stranded template that contains a region complementary to the oligonucleotide, DNA polymerase can use the oligonucleotide as a primer and elongate its $3^{\prime}$ end to generate an extended region of double stranded DNA.

\begin{tabular}{|c|c|c|}
\hline $\begin{array}{c}\text { Primer } \\
\text { Name }\end{array}$ & Sequence Details & $\begin{array}{c}\text { Sequence } \\
\text { Details }\end{array}$ \\
\hline $8 \mathrm{~F}$ & 5'AGAGTTTGATCCTGGCTCAG3' $^{\prime}$ & 20 \\
\hline 1541R & 5'AAGGAGGTGATCCAGCCGCA3' & 20 \\
\hline
\end{tabular}

Table 1. Details of primer used for 16srRNA sequencing 


\section{RESULT}

\section{A. Isolation of cellulolytic microorganism}

The fishes retrieved from aquarium were not found to possess the cellulolytic microbes in their gut, whereas the fishes from Cauvery river banks has considerable load of cellulolytic organisms. This might be due to lesser uptake of cellulosic feed by the aquarium fishes, when compared with native fishes.

\section{B. Detection of cellulolytic activity}

The cellulolytic activity was assessed by plating method (stained with $0.1 \%$ congo red and destained with $1 \mathrm{M} \mathrm{NaCl}$ ). The results demonstrated the formation of clear halo zone around the bacterial colonies. This indicates that the colonies exhibited cellulolytic activity by reducing the cellulose.

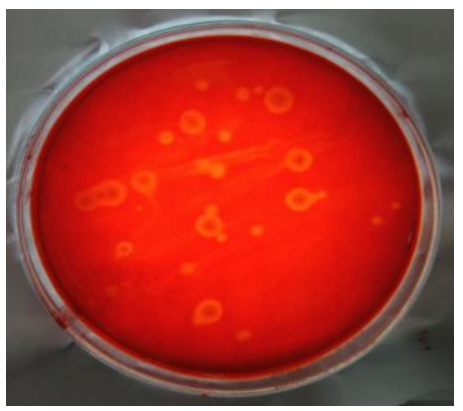

Fig. 5. Zone formation around colonies indicating the cellulolytic activity.

\section{Effect of substrate concentration on cellulase activity exhibited by the isolate}

Fig 6. shows that among the various concentrations of filter paper evaluated, maximum cellulase activity was exhibited at the concentration of $1 \mathrm{~g}$ of filter paper containing samples, which was verified by the increase in the absorbance values

\section{Characterization of Gut Isolate:}

The isolated bacteria was found to be gram negative, rod shaped and motile. The isolate exhibited a positive result for catalase (Fig. 7). After 24 hours of incubation in CMC, mostly they occur as single. The colonies in CMC agar plate were smooth and circular. The isolates were found to be facultative anaerobes.
E. 16S rRNA gene Sequencing :

The results of 16srRNA sequencing suggest that the isolated organism was found to be Enterobacter xiangfangensis

TGACGAGTGGGGGACGGGAGAGTAATGTCTGGGAAA CTGCCTGATGGAGGGGGATAACTACGGGAAACGGTA GCTAATACCGCATAACGTCGCAAGACCAGGGAGGGG GACCTTCGGGCCTCTTGCCATGGCATGTGCCGAGATG GGATTAGCTAGTAGGTGGGGTAACGGCTCACCTAGG CGACGATCCCTAGCTGGTCTGAGAGGATGACCAGCC GCACTGGAACTGAGACACGGTCCCGACTCCTACGGG AGGCAGGGATGGGGAATATTGGACAATGGGCGCAA GCCTGATGCACCGATGCCGCGTGTATGAAGAAGGCC TTCGGGTTGTAAAGTACTTTCAGCGGGGAGGAAGGC GATAAGGTTAATAACCTTGTCTGTTGACGTTACCCGC AGAACAAGCAACGGCTAACTCCGTGCCAGCAGCCGC GGTAATACGGAAGGTGCTAGCGTTAATCGGAATTAC TGGGCGTAAGGCGCACGCACGCGGTCTGTCAAGTCG GATGTGAAATCCCCGGGCTCAACCTGGGAACTGCAT TCGAAACTGGCAGGCTGGAGTCTTGTAGAGGGGGGT AGAATTCCAGGTGTCCGGTGAAATGCGTAAGATCTG GAGGAATACCGGTGGCGAAGGCGGCCCCCTGGACTA AGACTGACGCTCAGGTGCGAAAGCGTGGGGAGCAAA CAGGATTACATACCCTGGTAGTCCACGCCGTAGACG ATGTCGACTTGGAGGTTGTGCCCTTGAGGCGTGGCTT CCCGGAGCTAACGCGTTAAGTCGACCGCCTGGGGCA GTACGGGCCGCAAGGTTAAAACTAATATGAATTGAC GGGAGGCCCGCACAGCCGGTGGACCATGTGGTTTA

\section{F. Phylogenetic tree}

Phylogenetic tree obtained by the neighbor-joining method, based on the alignment of 16S rRNA gene sequencing (Fig. 8)

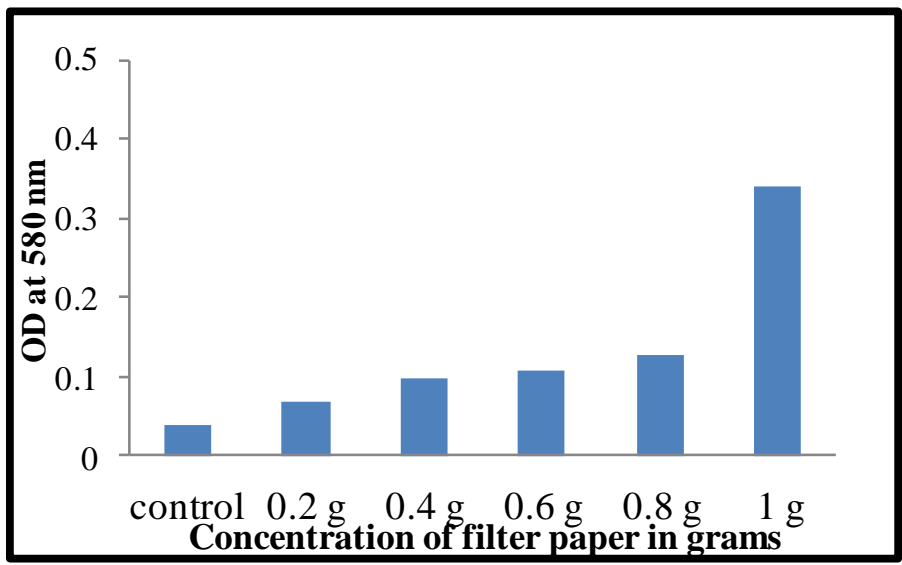

Fig. 6. Cellulase Activity 
International Journal of Engineering Applied Sciences and Technology, 2020

Vol. 5, Issue 1, ISSN No. 2455-2143, Pages 696-701

Published Online May 2020 in IJEAST (http://www.ijeast.com)

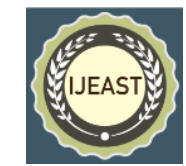

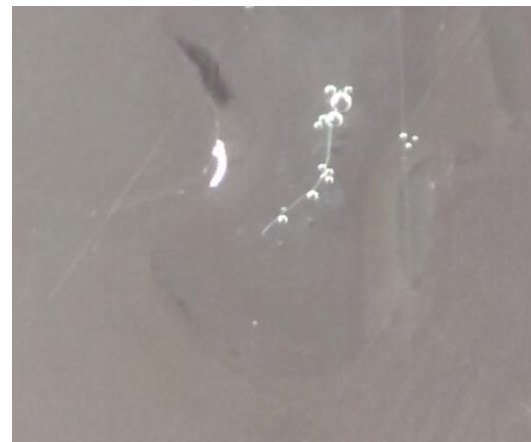

Fig. 7. Bubble formation in Catalase test
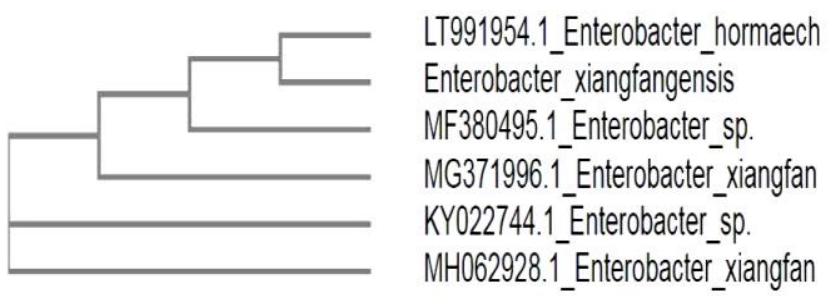

Fig. 8. Phylogenetic tree

\section{DISCUSSION}

$P$. multiradiatus is an invasive species in India which causes many troubles in aquatic ecosystem. The survival rate of $P$. multiradiatus is higher than other native fish species due to their bony plated scales in the outer body. These fishes were even found in sewage portals in all major cities. These fishes are highly suspected for pathogen carrying vector in urban water bodies due to their habitat. They are tolerant for variable $\mathrm{pH}$ and temperature. There is no natural predators for pleco fish in India. In order to keep the population of pleco fish under control, a thorough understanding about the fish is crucial, which will pave novel methods to control such invasive fishes. Isolation of cellulolytic microorganism from the gut of pleco fish (Parotocinclus maculicauda) was similarly done by Castro et al. 2011. They have isolated a novel strain designated as P118. In the present study, $E$. Xiangfangensis was isolated from the gut of pleco fish collected from the Cauvery river. E. xiangfangensis was isolated before from Chinese traditional sourdough $(\mathrm{Gu}$ et al. 2014). The fishes obtained from the river banks hold considerable amount of cellulolytic bacteria, which is due to the presence of many aquatic plants and algae in the river beds. The fishes collected from the aquarium showed no cellulolytic bacterial occurrence. Since the tanks were kept clean in aquarium, no aquatic plants or algae growth in that commercial aquarium environment was present. The aquarium fishes were forced to eat the artificial diet food which contains low level of cellulose. In order to avoid infections in fish, aquarium water was added with antimicrobial agents. Due to these conditions, bacterial count was very less in the gut of the fishes obtained from the Aquarium. The main purpose of this work is to control the population of pleco fish. Through this study, one can develop toxins specific for pleco fish, the population can be controlled and the exploitation of natural sources can be prevented, promoting the growth of other edible diverse populations. Moreover, the cellulase production of E. Xiangfangensis can be analyzed and upon further studies, the enzyme can be used in industrial production of cellulase enzyme.

\section{CONCLUSION}

In the present study symbiotic relationship between Enterobacter xiangfangensis and armoured catfish Pterygoplichthys multiradiatus has been identified in this study. The usage of Enterobacter xiangfangensis as a probiotic in aquaculture may increase the yield and increase in the usage of algal based feeds. The isolation of cellulolytic producing organisms from various sources will have a great impact on industrial production of cellulose enzyme.

\section{ACKNOWLEDGEMENT}

The authors gratefully acknowledge the support rendered by Srimad Andavan Arts and Science college, for carrying out the studies. They also would like to thank Mr. S. Ramanathan, Mr. R. Sathishkumar, Mr. R. Sasikumar for their help in collection of samples.

\section{REFERENCE}

[1] Armando, T.W.K,.Ramon R.C. \& Enrique A.A. (2007). Amazon sailfin cafish Pterygoplichthys paradalis (Castelnau, 1885) (Loricariidae), another exotic species established in south eastern Mexico. Southwestern Naturalist 52: 141-144

[2] Beguin, P. (1990) Molecular biology of cellulose degradation. Ann. Rev. Microbiol., 44: 219-248

[3] Bergman, E.N. (1990) Energy contributions of volatile fatty acids from the gastrointestinal tract. Physiol. Rev., 70: 567-590.

[4] Castro A.L.M.de, Vollú R.E., Peixoto R.S, LimaA.L.G, Coelho R.R.R, Bon E.P.S, Rosado.A.S., Seldin .L(2011). Cellulolytic potential of a novel strain of Paenibacillus sp. isolated from the armored catfish Parotocinclus maculicauda gut. Brazilian Journal of Microbiology 42: 1608-1615

[5] Gu. C.T, Li.C.Y, Yang.L.J and Huo.G.C. (2013). Enteroabacter xiangfangensis sp. Nov., isolated from Chinese traditional sour dough, and reclassification of Enterobacter sacchari Zhu et al. International Journal of Systematic and Evolutionary Microbiology 64: 2650-2656 


\section{International Journal of Engineering Applied Sciences and Technology, 2020 \\ Vol. 5, Issue 1, ISSN No. 2455-2143, Pages 696-701 \\ Published Online May 2020 in IJEAST (http://www.ijeast.com)}

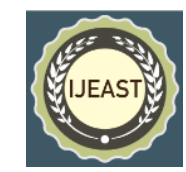

[6] Golani,D. \& Snovsky.G (2013). Occurrence of suckermouth Armoured Catfish (Siluriformes, Loricariidae, Pterygoplichthys) in inland waters of Israel. Bioinvasions Records 2: 253-256

[7] Hossain, M.Y, Rahman.M.M, Ahmed Z.F, Ohtomi.J \& Islam.A.B.M.S. (2008). First record of the South American sailfin catfish Pterygoplichtys multiradiatus in Bangladesh. Journal of Applied. Ichthyology 24: 718-720

[8] Hubilla.M, Kis.F \& Primavera.J (2007). Janitor fish Pterygoplichthys disjuctivus in the Agusan marsh: a threat to freshwater biodiversity. Journal of Environmental Science and Management 10: 10-23

[9] Huang.S, Sheng.P and Zhang.H (2012). Isolation and Identification of Cellulolytic Bacteria from the Gut of Holotrichia parallela Larvae (Coleoptera: Scarabaeidae) International Journal of Molecular Sciences 13: 25632577;

[10] Irfan.M, Safdar.A, Syed.Q and Nadeem.M (2012).Isolation and screening of cellulolytic bacteria from soil and optimization of cellulase production and activity, Turkish Journal of Biochemistry 37: 287-293.

[11] Knight .J.D.M.(2010). Invasive ornamental fish: a potential threat to aquatic biodiversity in peninsular India. Journal of Threatened Taxa 2: 700-704

[12] Kasana.R.C, Salwan.R, Dhar.H, Dutt.S, Gulati.A(2008). A Rapid and Easy Method for the Detection of Microbial Cellulases on Agar Plates Using Gram's Iodine Curr Microbiol 57:503-507

[13] Nakova, T.(ed.)(2002). Fishes of Japan with Pictorial keys to the Species, English edition, Tokai University Press, Tokyo.

[14] Nico, L.G, Butt P.L, JohnsonG.R, Jelks .H.L, Kail.M \& Walsh.S.J. (2012). Discovery of the South American Suckermouth Armoured Catfish (Loricariidae, Pterygoplichthys spp.) in the Santa Fe River drainage, Suwannee River basin, USA. Bioinvasion Records 1: 179200

[15] Ozdilek,S.Y. (2007). Possible threat for middle east inland water: an exotic and invasive species, Pterygoplichthys disjunctivus (Wever,1991)in asi river, Turkey. Journal of Fisheries and Aquatic Scienes 24: 303-306

[16] Padilla, D.D \& Williams S.L. (2004). Beyond ballast water: aquarium and ornamental traders as source of invasive species in aquatic ecosystems. Frontiers in ecology and the environment 2: 131-138

[17] Page. L.M. \& Robins R. H. (2006). Identification of sailfin catfishes (Teleosti: Laricariidae) in south eastern Asia. The Raffles Bulletin of Zoology 54: 455-457

[18] Ray A.K., Ghosh K. and Ringo. E (2012). Enzyme producing bacteria isolated from fish gut: a review, Aquaculture nutrition.
[19] Rixon. C.A.M, Duggan.I.C, Bergeron N.M.N, Ricciardi.A \& Macissac.H.J (2005). Invasion risks posed by the aquarium trade and live fish markets on Laurentian Great Lakes. Biodiversity and Conservation 14: 1365-1381

[20] Sandeep. C; Ingle.S, Patel.D and Thakkar.B(2017). Isolation of bacteria producing cellulase from tilapia fish gut and media optimization for celluase production using Plackett Burman design, International Journal of Biotech Trends and Technology 7: 13-18

[21] Saptarini.N.M, Indriyati.W(2014). Isolation of cellulolytic bacteria from termites with cellulose of corn cobs As a carbon source International Journal of Pharmacy And Pharmaceutical Sciences 215-217

[22] Sumanasinghe, H.P.W. \& Amarasinghe U.S. (2013). Population dynamics of accidentally introduced Amazon Sailfin Catfish, Pterygoplichthys paradalis (Siluriformes, Loricariidae)in pologolla reservoir, Sri Lanka. Sri Lanka Journal of Aquatic Sciences 18: 37-45

[23] Wilson. D.B. \& Irwin, D.C. (1999) Genetics and properties of cellulases. In: Recent Progress in Bioconversion of Lignocellulosics. Advances in Biochemical Engineering/Biotechnology 1-21.

[24] Wu. L.W, Liu.C.C \& Lin.S.M. (2011). Identification of exotic Sailfin Catfish species (Pterygoplichthys, Loricariidae) in Taiwan based on morphology and mtDNA sequences. Zoological Studies 50: 235-246

[25] Zworykin D.D. \& Budaev S.V. (2013). Non- indigenous armoured catfish in Vietnam: invasion and systematic. Ichthyological Research 60: 327-333 